\title{
A DESCRIPTIVE STUDY TO ASSESS THE KNOWLEDGE AND PRACTICE OF PREMENSTRUAL SYNDROME AMONG ADOLESCENT GIRLS IN SELECTED SCHOOLS OF AMRITSAR, PUNJAB
}

Dr. Arundeep Kaur* \& Dr. Harleen Kaur* *Associate Professor, CKD International Nursing College, Amritsar, Punjab, India. DOI: http://doi.org/10.47211/idcij.2020.v07i03.010

Received $15^{\text {th }}$ May 2020, Accepted 25 ${ }^{\text {th }}$ May 2020, Available online $10^{\text {th }}$ July 2020.

\begin{abstract}
Menstruation is a normal physiological process in each in each girl's life. It is a monthly uterine bleeding for 35 days after every 28days from puberty till menopause. A change in mood, behaviour and appearance are some of vague symptoms often noticed in the second half of cycle. But if the symptoms are severe enough to disturb lifecycle of women or require medical help, it is called premenstrual syndrome. India has one of the fastest growing youth population in the world with an estimated 190 million adolescent girls below 19 years of age, comprise one quarter of India rapidly growing population. During this period of adolescence, individuals move toward physical and psychological maturity and acquire their adult identity and therefore require special attention and care to cope up with the problems like PMS. For the present study Non-experimental approach and descriptive research design was used. The setting of the study was Dashmesh Parivar School, Amritsar. The Population of present study was adolescent girls. Study was conducted on 100 adolescent girls from Dashmesh parivar school, Amritsar (Punjab) who were selected by using purposive sampling Technique. A self-structured questionnaire was proposed to assess the knowledge and practices. Results revealed that majority 52\% adolescent girls were from age group 12-14 years. Maximum 62\% belonged to low income group and majority were from nuclear family. Mostly girls got information regarding PMS from family members. Most of girls $79 \%$ were having average knowledge and maximum 69\% were having good practice related to PMS. There was no significant relationship between knowledge and practice. There was significant association of knowledge with socio demographic variables.
\end{abstract}

KEYWORDS: Descriptive study, premenstrual syndrome, adolescent girls. 


\section{INTRODUCTION}

Menstruation is a normal physiological process in each in each girl's life. It is a monthly uterine bleeding for 35 days after every 28 days from puberty till menopause. A change in mood, behaviour and appearance are some of vague symptoms often noticed in the second half of cycle. But if the symptoms are severe enough to disturb lifecycle of women or require medical help, it is called premenstrual syndrome (PMS).

Coffee (2006) premenstrual symptoms are common in ovulating women and can influence quality of life. Symptoms occur in the luteal phase and disappear with the onset of menses.PMS is a combination of bothersome symptoms and premenstrual dysphoric disorder is a severe type of premenstrual disorder that significantly impairs normal activity.

\section{NEED OF STUDY}

India has one of the fastest growing youth population in the world with an estimated 190 million adolescent girls below 19 years of age, comprise one quarter of India rapidly growing population. During this period of adolescence, individuals move toward physical and psychological maturity and acquire their adult identity and therefore require special attention and care to cope up with the problems like PMS. Navdeep kaur, Ramesh Thakur (2009) said that Premenstrual syndrome is the primary reason by women to miss work, school or college. Sometime their symptoms are so severe that they need medical care.

\section{STATEMENT:}

A Descriptive study to assess the knowledge and practice of premenstrual syndrome among adolescent girls in selected schools of Amritsar, Punjab.

\section{AIM OF THE STUDY}

To improve the knowledge and practice regarding premenstrual syndrome among adolescent girls by providing guidelines related to premenstrual syndrome.

\section{METHODOLOGY}

For the present study was non- experimental approach and descriptive research design was used. The setting of the study was Dashmesh Parivar School, Amritsar. The Population of present study was Adolescent girls. Study was conducted on 100 adolescent girls from Dashmesh parivar school, Amritsar (punjab). The sample of 100 adolescent girls was selected with purposive sampling technique. A self structured questionnaire was proposed to assess the knowledge and practices. Tool included two parts: Part A: Sociodemographic profile included personal information about subjects such as Age in years, family income, type of family, area of residence, source of information. Part B: self structured questionnaire.

The tool had 31 questions; 19 questions were related to knowledge and 12 question were related to practice of adolescent girlsto manage premenstrual syndrome. The data was collected within the prescribed time period in selected high schools Amritsar, Punjab. Permission was obtained from higher authority. Purpose of the study was explained to the respondents. Knowledge was assessed using self structured questionnaire. Planned structured teaching programme was given on the same day.

\section{RESULTS}

$52 \%$ adolescent girls were from age group 12-14 years. $62 \%$ belonged to low income group and majority were from nuclear family. Mostly girls got information regarding PMS from family members. $79 \%$ of girls were having average knowledge and $69 \%$ of girls had good practice related to PMS. There was no significant relationship between knowledge and practice. There was significant association of knowledge with socio demographic variables.

\section{CONCLUSION}

Most of the girls were having adequate knowledge regarding PMS and maximum girls (69\%) were found to have good practices related to PMS. 